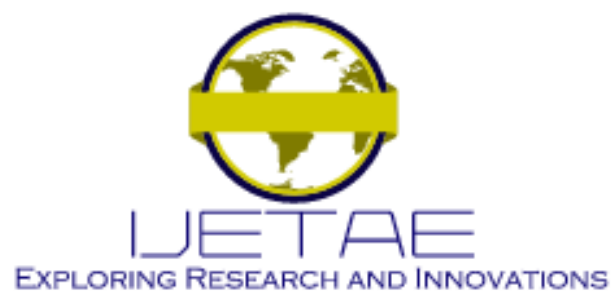

International Journal of Emerging Technology and Advanced Engineering

Website: www.ijetae.com (E-ISSN 2250-2459, Scopus Indexed, ISO 9001:2008 Certified Journal, Volume 11, Issue 11, November 2021)

Manuscript Received: 06 October 2021, Received in Revised form: 07 November 2021, Accepted: 12 November 2021 DOI: 10.46338/ijetae1121_15

\title{
Implementation of a Thermal Image Processing System to Detect Possible Cases of Patients with COVID-19
}

\author{
Brian Meneses-Claudio ${ }^{1}$, Luis Nuñez-Tapia ${ }^{2}$, Witman Alvarado-Díaz ${ }^{3}$, Alicia Alva Mantari \\ ${ }^{1,2,3}$ Universidad de Ciencias y Humanidades \& Av. Universitaria 5175, Los Olivos
}

\begin{abstract}
COVID-19 does not show signs of having disappeared, being a very contagious disease, the WHO recommended limiting the free movement of people, since from its appearance until May $1^{\text {st }}, 2021$, it caused the death of more than 3.2 million of people around the world. In Peru, it economically affected those people who generated income every day to survive, for this reason some activities were reactivated complying with the biosafety measures that are the use of mandatory mask and social distancing (more than 1 meter). Taking body temperature with an infrared thermometer is an optional measure, generating rejection by specialists, indicating that there is little evidence of its sensitivity and specificity and of its doubtful ability to detect fever. In view of this problem, this article will implement a thermal image processing system to detect possible cases of patients with COVID-19, in such a way that the system performs a more accurate measurement of body temperature, and it can be implemented in any place where such measurement is intended, helping to combat the spread of the virus that currently continues to affect many people. The system has a more accurate measurement of body temperature with an efficiency of $95 \%$ at 1 meter between the drone and the person, in such a way that if it presents a body temperature higher than $40^{\circ} \mathrm{C}$ it could be infected with COVID-19.
\end{abstract}

Keywords-- Thermal camera, COVID-19, Drone, MATLAB, WHO, Image processing.

\section{INTRODUCTION}

COVID-19 shows no sign of ending, originating in the city of Wuhan (China), it has claimed the lives of many people in China and in various parts of the world [1]. Being a highly contagious viral infection caused by SARS-CoV-2 [2], the World Health Organization (WHO) announced it as a pandemic [3] on March $11^{\text {th }}, 2020$ [4]. Until May $1^{\text {st }}$, 2021 , caused the death of more than 3.2 million people worldwide [2]. For this reason, the World Health Organization (WHO) recommended that all countries limit the free movement of people outside their homes [5].
Being an unprecedented infection in the health of people worldwide, the Peruvian government decided to declare a state of emergency at the national level, closing the borders and canceling any activity that generates an agglomeration of people, considering the recommendations declared by the World Health Organization (WHO). Markets were only allowed to open for people to buy their food [6], this greatly affected the economy of many people, so they demanded that the Peruvian government be able to reactivate some activities so that they can work [7]. Faced with this need on the part of the people, the government decided to reactivate some activities so that people can work. For this, a series of biosecurity measures were imposed that they must comply with, which are the use of a mandatory mask and avoid the crowding of people within the place to respect social distancing, which must be more than 1 meter [8]. Within the measures imposed by the government, some companies have also chosen to wash the hands of all their workforce before entering their workplace.

A measure that is observed a lot when entering a shopping center is the measurement of body temperature with the use of an infrared thermometer with the use of gel alcohol on people's hands [9]. This new biosecurity measure has generated rejection by specialists, indicating that there is little evidence of its sensitivity and specificity [10], also of its doubtful ability to detect fever and to classify people in the appropriate thermal category, due to because the measurement made by the infrared thermometer can be affected by factors such as (direct contact with hot or cold surfaces), which can cause false or erroneous readings [11]. Being inaccurate, the infrared thermometer will show a different reading each time there is a change in ambient temperature [12].

The objective of this research work is to implement a thermal image processing system to detect possible cases of patients with COVID-19, in such a way that it has a more accurate measurement of people's body temperature unlike infrared thermometers that they are commonly used, helping to reduce the number of infections. 


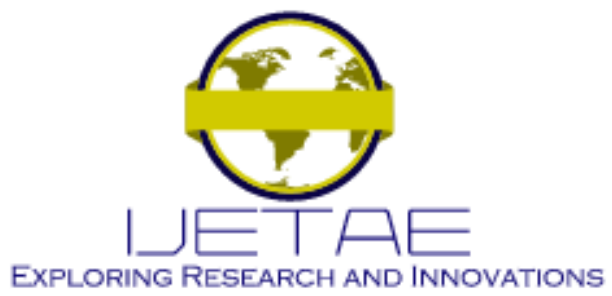

International Journal of Emerging Technology and Advanced Engineering Website: www.ijetae.com (E-ISSN 2250-2459, Scopus Indexed, ISO 9001:2008 Certified Journal, Volume 11, Issue 11, November 2021)

For the elaboration of the implementation, a drone was used that will take photos with a thermal camera of different people and, through the image processing developed in MATLAB, indicates the body temperature and our interest zone is the forehead.

The MATLAB mathematical software allows us to perform numerical calculations with vectors and matrices and is very useful for image processing since it allows us to manipulate images.

In section II, the methodology will indicate the electronic part and design of the system. In section III, the results that are generated according to the tests carried out with the system design will be presented. In section IV the discussion will be presented, where the importance of the present work will be indicated with respect to other works carried out. Finally, in section V, the conclusion and recommendation obtained from the design of the system will be presented.

\section{LITERATURE REVIEW}

By not having an accurate measurement of body temperature with the infrared thermometer, automated systems with medical grade body temperature measurement are essential and meet a more accurate measurement. For example: In [13], the authors identified that commercial premises are not complying with the minimum distance of 2 meters between the employee and the client at the time of taking the temperature and disinfecting hands that are carried out manually, that is why they proposed to develop a web system to monitor body temperature with an automatic antibacterial gel dispenser to prevent COVID-19 infections in commercial premises of Guayaquil. The proposed method consists of using the Arduino mega to develop the temperature measurement and hand disinfection system to automate the current process carried out by the personnel in charge, through the PHP programming language a web system is developed to monitor the temperatures taken obtained from the MYSQL database, thus leading to greater control of the cases. Obtaining as a result an efficiency of $98.1 \%$, the body temperature measurement system will provide antibacterial gel for those with a normal temperature (less than or equal to $37.5^{\circ} \mathrm{C}$ ) and restrict access to those with a high temperature (greater than $37.5^{\circ}$ C), concluding that the project is optimal in terms of time and costs, this is due to the technological tools used that are open source, thus allowing them to be used freely and easily.
In [14], the authors identified that with the arrival of COVID19, the measurement of body temperature in people is frequently observed, but that these devices are those thermometers that are sold in the market and these devices cannot have three points Keys: the error, the automatic measurement and the way to treat large amounts of data, that is why they proposed to develop an automatic recording system of the temperature measurement on the forehead. The proposed method is that when the infrared temperature sensor MLX90614 detects the temperature on the user's forehead and this value exceeds $34^{\circ} \mathrm{C}$, the user's RFID card approaches the card reader to read the card number and is transferred to a computer through the USB interface, then all the data obtained is stored in the designated data table in the database that can be viewed by a computer or an App on the mobile phone. Obtaining as a result an accuracy rate of $98.5 \%$, concluding that, if the number of people increases, the management interface may also have an additional level of authority management function.

In [15], the authors identified that with the current COVID-19 pandemic, early detection of symptoms and adequate hygienic standards are important, especially in places where people are in random contact and necessary measures could combat the virus that infected more than five million people and the numbers continue to increase, that is why they proposed to carry out an automated evaluation of the risk factors of COVID-19 together with personal location data in real time and indoors for potential disease identification, prevention and smart quarantine. The proposed method consists of using a Raspberry Pi 4 Model $\mathrm{B}$ that allows real-time processing of all the data of the images and sensors, a Raspberry Pi v2 camera module for the detection of the face mask and facial navigation on the screen, an MLX90614 infrared thermometer with medical grade precision $\left( \pm 0.1{ }^{\circ} \mathrm{C}\right)$, a VL53L0X time-of-flight distance sensor for presence detection and finally a 7 "Raspberry Pi capacitive LCD module with 800x480px resolution, where it will have a LAN or Wifi connection to write the information to the SQL database server. Obtaining an efficiency of $97.7 \%$ as a result, since the system detects whether the person wears a hygienic / protective mask and has a temperature below $<37.0{ }^{\circ} \mathrm{C}$, concluding that this system can help to automatically assess body temperature at various control points and by enforcing proper hygiene standards related to the masks. 


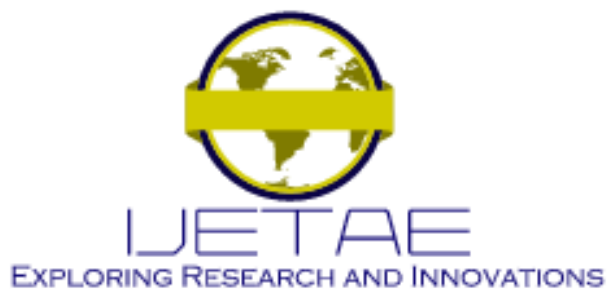

International Journal of Emerging Technology and Advanced Engineering

Website: www.ijetae.com (E-ISSN 2250-2459, Scopus Indexed, ISO 9001:2008 Certified Journal, Volume 11, Issue 11, November 2021)

In [9], the author identified that the arrival of COVID-19 brought global health crisis in the mining sector, generating major changes in the digital and technological field, to monitor standards, to foresee potential risks or to optimize processes and reduce risks, entering this industry by leaps and bounds, which is why he developed a security monitoring and prevention measures of COVID-19 contagion through detection in CCTV system for mining. The proposed method consists of using COCO dataset in a CenterNet network architecture to detect people, also used YOLO Darknet for the YOLOv5 network and the use of the Roboflow platform. They obtained as a result an efficiency of $98 \%$, concluding that the system informs about social distancing, the use of masks, helmets and surveillance of restricted areas in an effective way.

In [16], the authors identified that diagnostic tests are a central tool in the fight against the pandemic, these tests are based on antigen-antibody recognition and provide results in several minutes, their main problem is that they are qualitative and only report the presence of antibodies, which indicates an active infection or having passed such infection. Therefore, they proposed to develop a COVID-19 detection system using biosensors based on graphene transistors. The proposed method consists of using biosensors based on graphene transistors to develop a microfluidic chip integrated on a graphene FET sensor array. As a result, a detection efficiency of $96 \%$ was obtained, concluding that the system is easy to use, fast (seconds from sample collection to result) and ultrasensitive to detect immunoglobulins against SARS-CoV-2 S protein.

Finally, in [17] ,the authors identified that, to reduce the number of infections in workers within their workplace, it is necessary to measure the body temperature of each worker, because a common symptom of COVID-19 is fever and that if he or she has a high body temperature he or she could be infected, that is why they proposed a system for detecting employee fever with the thermal camera integrated in the attendance management system, thus using a thermal camera, which has a heat sensor and can detect any temperature difference, even with a hot cup of coffee it will not go wrong and will give accurate results.
Obtaining as a result an efficiency of $99.78 \%$, since when the thermal camera detects a body temperature lower than $99^{\circ} \mathrm{F}\left(37^{\circ} \mathrm{C}\right)$ it gives the green light, otherwise it is not allowed to enter at workplace, concluding that there are some limitations like camera accuracy and situations like an infected person not showing the highest temperature or an uninfected person showing the temperature rise.

\section{Methodology}

In this part, the design of the thermal image processing system will be carried out to detect possible cases of patients with COVID-19. With this system, the person's body temperature will be measured and observed if they have a fever, which is a common symptom of COVID-19.

\section{A. Drone potensic $T 25$}

The potensic T25 drone as shown in figure 1, is an unmanned aerial device that will allow the person to take a photo to later analyze the body temperature with the help of the thermal camera. This device has the following characteristics [18]:

- 1080P FHD Camera.

Angle adjustable from 0-90.

- Capture high-quality video.

- Capture aerial photos reaching a height of 300 meters.

o It has a $3.7 \mathrm{~V} 1000 \mathrm{mAh}$ battery.

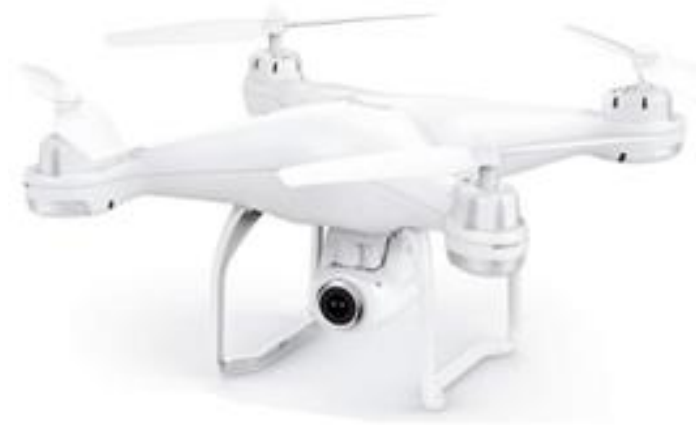

Fig. 1. Drone Potensic T25

To use the Potensic T25 drone, you need to perform the calibration as follows:

○ Take the drone vertically, as shown in figure 2 , and rotate $360^{\circ}$. 


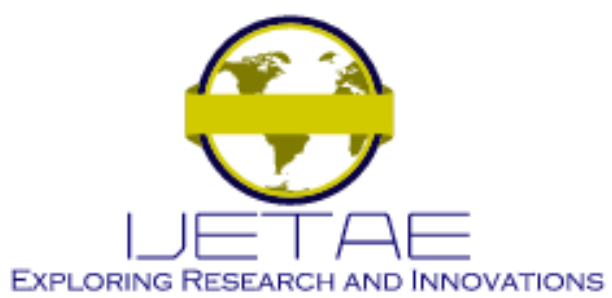

International Journal of Emerging Technology and Advanced Engineering

Website: www.ijetae.com (E-ISSN 2250-2459, Scopus Indexed, ISO 9001:2008 Certified Journal, Volume 11, Issue 11, November 2021)

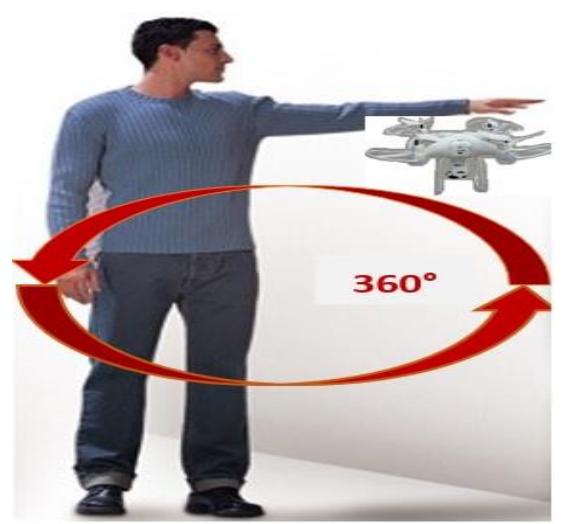

Fig. 2. Rotate the vertical drone $360^{\circ}$

$\circ$ Take the drone upside down, as shown in figure 3, and rotate $360^{\circ}$.

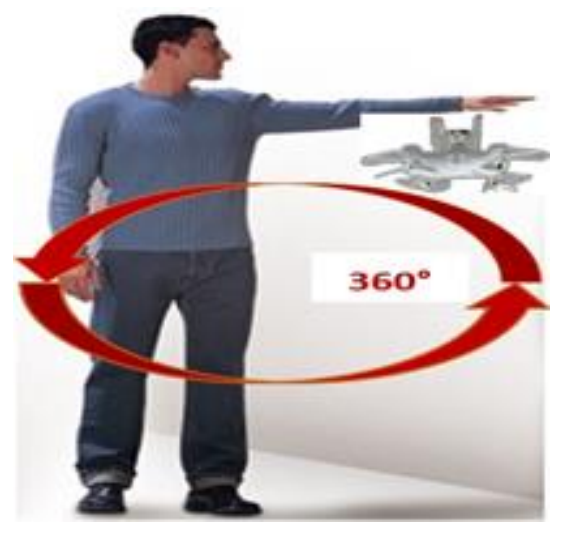

Fig. 3. Rotate the inverted drone $360^{\circ}$

It is also necessary to know the dimensions of the

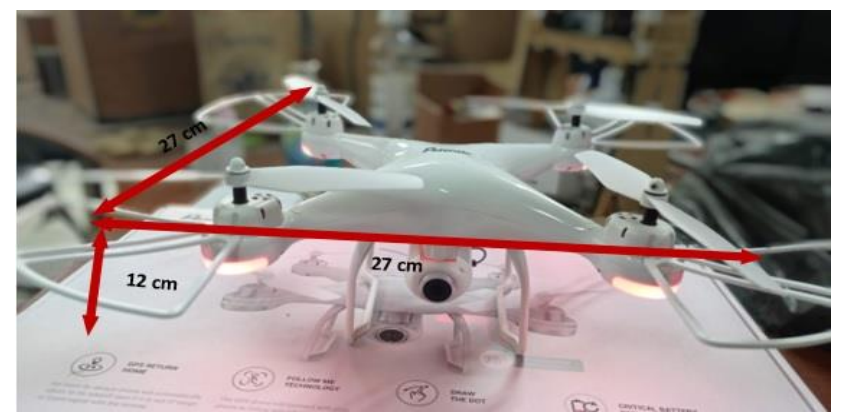

Potensic T25 drone of $27 \times 27 \times 12 \mathrm{~cm}$, as shown in Figure 4.
The Potensic T25 drone has its own Potensic G application, as shown in Figure 5, which allows us to link it with the cell phone to control it, take photos and record video, as shown in figure 6.

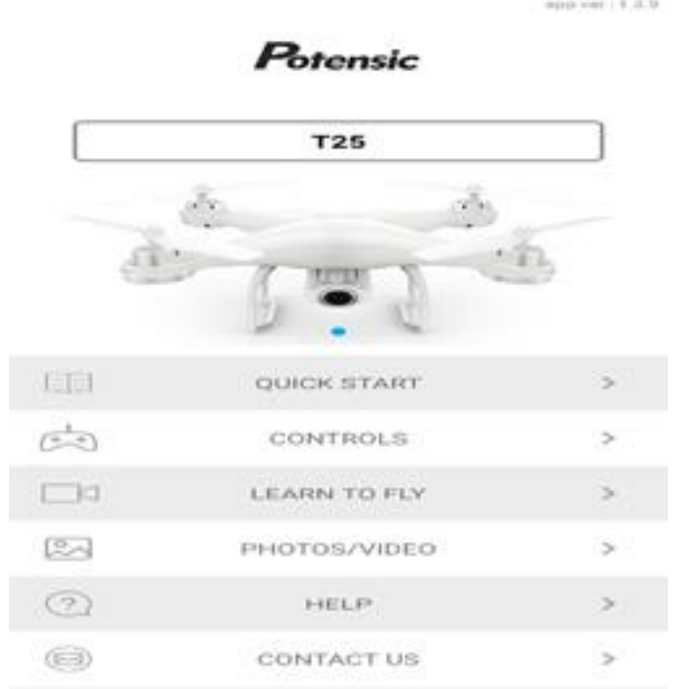

Fig. 5. Model of the selected drone

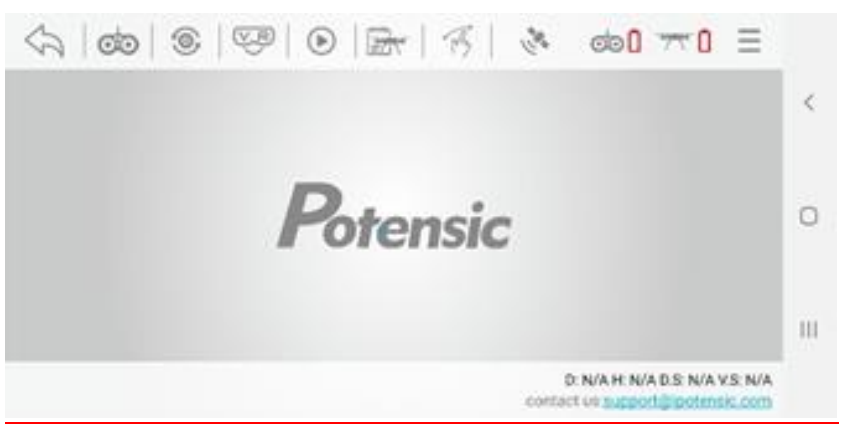

Fig. 6. Interaction with the drone through the Potensic G application

\section{B. Average Height}

The average height in which the drone could be is 150 to $180 \mathrm{~cm}$, this is possible because the drone has an angular adjustment that goes from $0^{\circ}$ to $90^{\circ}$ as mentioned above. In addition, these values were considered because the average height of the Peruvian population is $165.3 \mathrm{~cm}$ for men and $152.9 \mathrm{~cm}$ for women, thus being the lowest height in the world according to a study carried out by Harvard University [19]. For example, in Figure 7 the drone is at a height of $172 \mathrm{~cm}$ and in Figure 8 the drone is at a height of $184 \mathrm{~cm}$. 


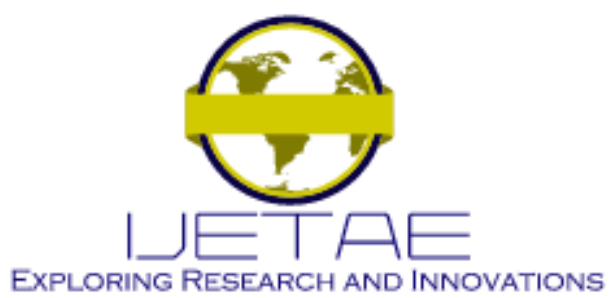

International Journal of Emerging Technology and Advanced Engineering

Website: www.ijetae.com (E-ISSN 2250-2459, Scopus Indexed, ISO 9001:2008 Certified Journal, Volume 11, Issue 11, November 2021)

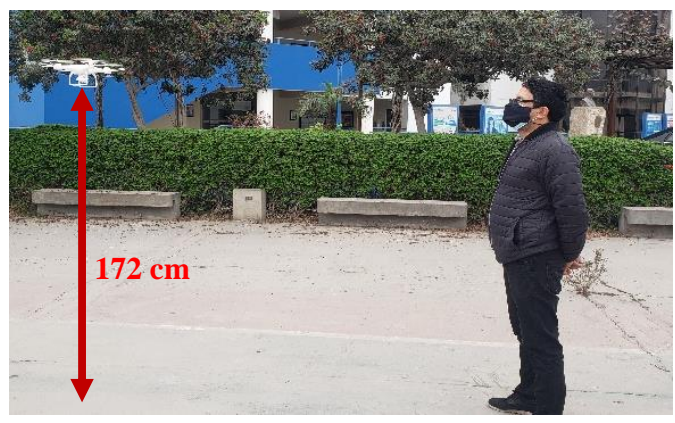

Fig. 7. Drone $172 \mathrm{~cm}$ high

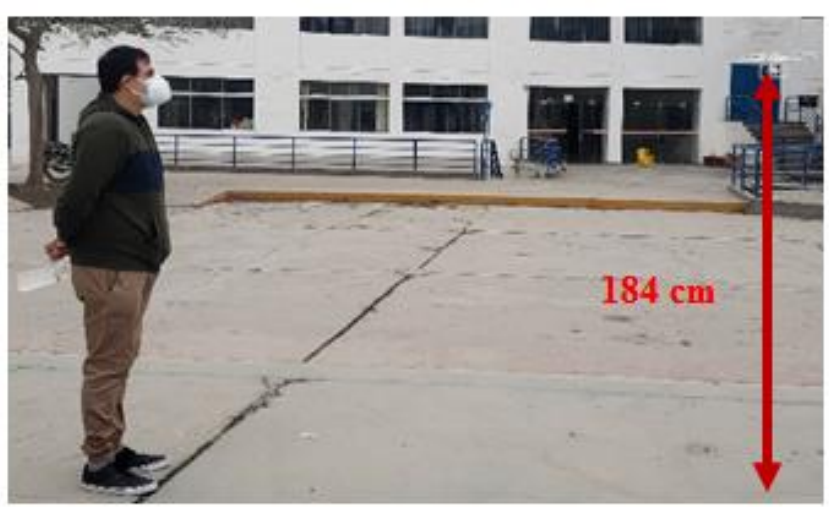

Fig. 8. Drone $184 \mathrm{~cm}$ high

\section{FLIR ONE Pro}

The FLIR ONE Pro is a thermal camera that with the help of the drone, will take photos of people according to their corresponding height. Figure 9 shows the FLIR ONE Pro that has 2 lenses, the upper lens is from the normal camera and the lower lens is from the thermal camera. In addition, it is compatible with Android and IOS mobile devices and has its own software to process thermal images. This device has the following characteristics [20]:

○ Dimension of $68 \times 34 \times 14$ millimeters

$\circ$ Weight of 36.5 grams

$\circ$ Operating time of 1 hour

- Temperature range from $-20^{\circ} \mathrm{C}$ to $-400{ }^{\circ} \mathrm{C}$

- $160 \times 120$ thermal resolution

$\circ \quad$ Maximum operating distance of 1.8 meters

- Compatible with Android and IOS

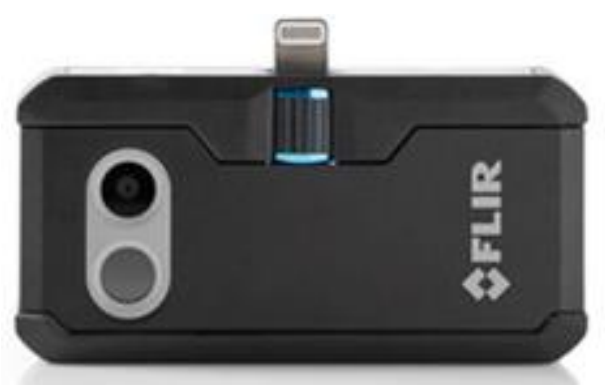

Fig. 9. FLIR ONE Pro Thermal Camera

The operation of the thermal camera on the mobile device is very simple, you just must connect both devices and once connected open the FLIR ONE application to be able to take the corresponding photo, as shown in figure 10 .

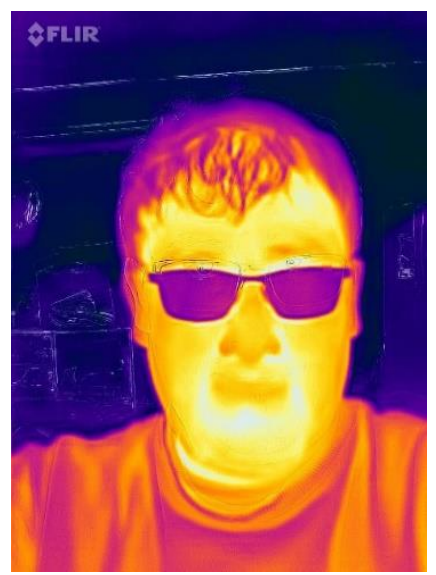

Fig. 10. Focusing the FLIR ONE camera

\section{Drone position}

The position of the drone in front of the person, must be in the range of 1 to 2 meters, because it is a distance recommended by various specialists as mentioned above. It is necessary that the drone camera does not have any obstacles, and in addition to not flying over the drone in very closed places, this could cause damage to the drone and even to the person himself, as shown in Figure 11. 


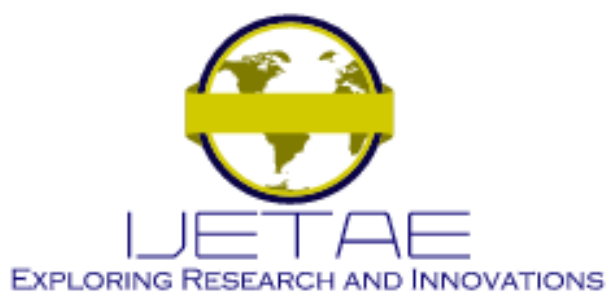

International Journal of Emerging Technology and Advanced Engineering

Website: www.ijetae.com (E-ISSN 2250-2459, Scopus Indexed, ISO 9001:2008 Certified Journal, Volume 11, Issue 11, November 2021)

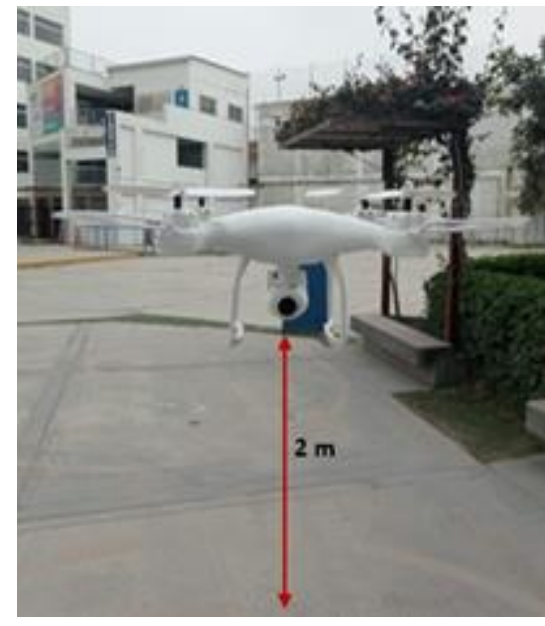

Fig. 11. Posición del drone Potensic T25

\section{E. MATLAB}

MATLAB software is a useful tool for performing digital image processing in different professional areas such as medical diagnostics, astronomy, pattern matching and recognition (vehicle license plate recognition, fingerprint and palm recognition) for security applications, forensic analysis, geographic information systems, human computer interfaces, industrial inspection, document processing, remote sensing, satellite image processing, and wireline and wireless image transmissions [21].

The basic picture element is called a pixel, and a $M \times N$ image has $\mathrm{M}$ rows of pixels and $\mathrm{N}$ columns of pixels. You can also think of a $2 \mathrm{D}$ grid or matrix whose elements are represented by $\mathrm{f}(\mathrm{x}, \mathrm{y})$, where $\mathrm{x}$ and $\mathrm{y}$ are the coordinates of the grid or the indices of the elements of the matrix [21].

The types of image processing that are applied to an RGB image are, for example: "grayscale", uses different shades of gray in an image. In 8-bit images, there can be up to 256 shades of gray. Each pixel in a grayscale image has a brightness value between 0 (black) and 255 (white) [22]. Another is "binarization", it converts the digital image into a black and white image, in such a way that the essential properties of the image are preserved. One of the methods to be able to binarize a digital image is by means of the histogram of said image [23]. Another is "pixel mapping", it records an arbitrary number of moving images with respect to the fixed image (reference) [24]. Another is "subtraction of images", it subtracts each element of the matrix from the corresponding element of the matrix and returns the difference in the corresponding element of the output matrix [22].

\section{F. Image Processing Techniques}

An RGB image (Red, Green, Blue) is so called any color image, which, by mixing these three primary colors, can have a certain color that would represent the image. It should be noted that each color can range from 0 to 255 bits that each pixel would represent.

To be able to analyze an RGB image in MATLAB software, it is necessary to declare it using some commands, as shown below:

RGB= imread ("termica.jpeg");

imshow (RGB);

[R,G,B]= imsplit (RGB); imshow $(\mathrm{R})$

A grayscale image or RGB2GRAY, converts an RGB image to grayscale, that is, it changes the intensity of each color in values of 0 (black) and 1 (white).

To analyze a grayscale image in MATLAB software, you need to use a few commands, as shown below:

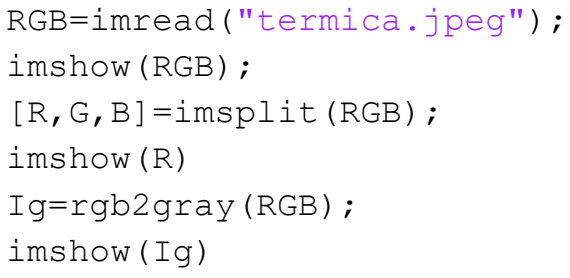

A binary image, or IM2BW, converts a grayscale image to a binary image by replacing the pixels in the input image with luminance greater than the value (white) and replacing all other pixels with the value (black).

To be able to analyze a binary image in MATLAB software, you need to use some commands, as shown below:

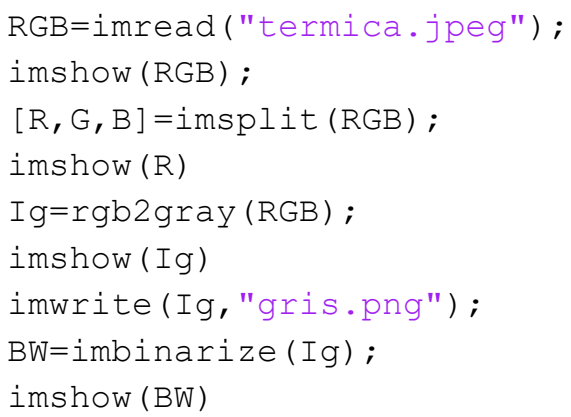




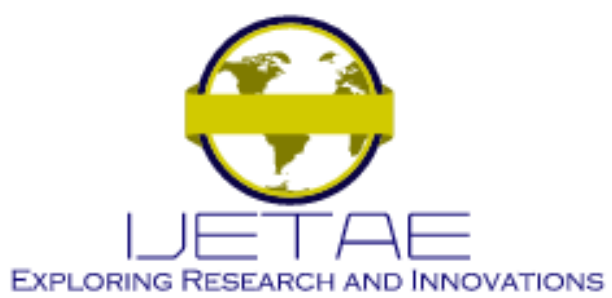

International Journal of Emerging Technology and Advanced Engineering

Website: www.ijetae.com (E-ISSN 2250-2459, Scopus Indexed, ISO 9001:2008 Certified Journal, Volume 11, Issue 11, November 2021)

\section{G. Sectorize the area of interest}

To sectorize the area of interest, it is necessary to indicate through MATLAB programming that when the thermal camera takes the photo, the system focuses on the part of the person's forehead, to indicate the degree of temperature that the image presents. person. As in Figure 12, the photo taken by the thermal camera is observed; If a person has hair on the forehead, the system can still detect the temperature that the person has.

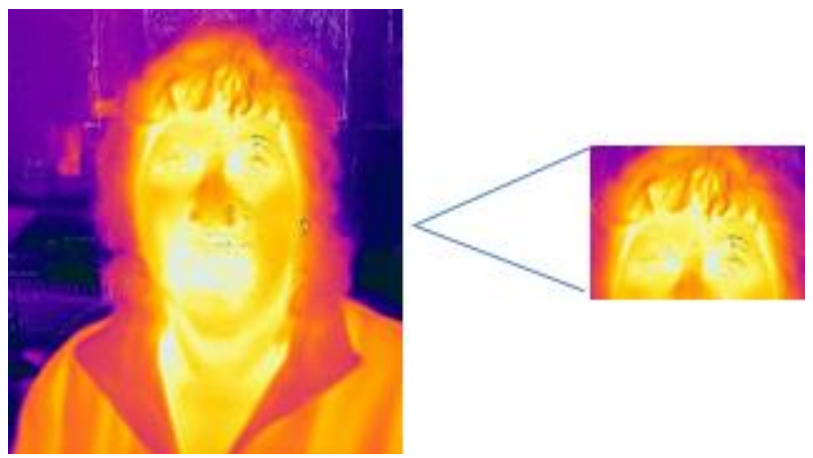

Fig. 12. Photo of the thermal camera

\section{H. Body temperature}

Body temperature is an important factor currently being considered because it is related to fever, a symptom that is related to COVID-19.

The measurement of body temperature is taken when you want to enter a place where the public is allowed, for example, supermarkets, banks, etc. This measurement is made on the forehead or wrist of the person.

The range where a normal temperature is considered is between $36.1{ }^{\circ} \mathrm{C}$ to $39.1{ }^{\circ} \mathrm{C}$ [25], that is why the present system will work in a temperature range of $15^{\circ} \mathrm{C}$ to $40{ }^{\circ} \mathrm{C}$, thus as shown in Figure 13, because according to the US Center for Disease Control and Prevention it considers that a person has a fever if their body temperature is above $40{ }^{\circ} \mathrm{C}$ [25].

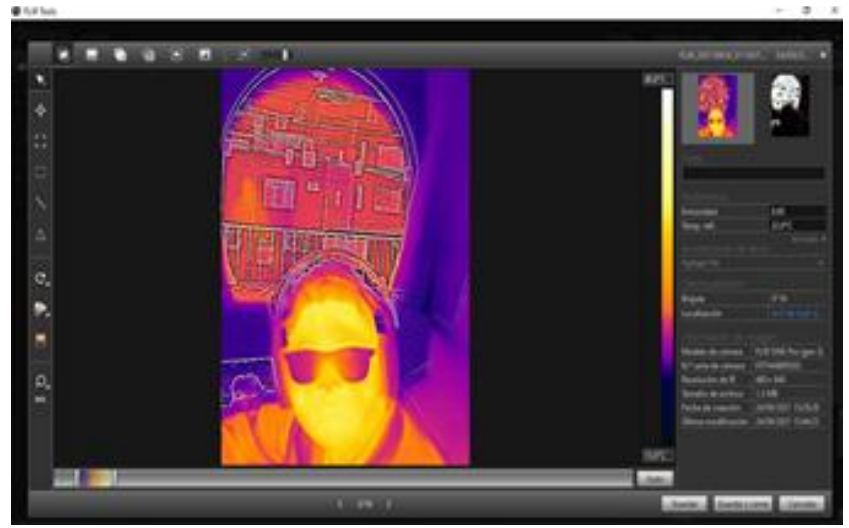

Fig. 13. Thermal camera analysis

\section{RESULTS}

With the implementation of the thermal image processing system to detect possible cases of COVID-19 patients, the objective of having a more accurate measurement of body temperature, with an efficiency of $95 \%$, would be being met.

By using this system, the body temperature of any person can be more accurately known, as shown in Figure 14 (a), it is collected by the thermal camera, while in Figure 14 (b), It is the image analyzed through thermal image processing to indicate the value of the person's body temperature.

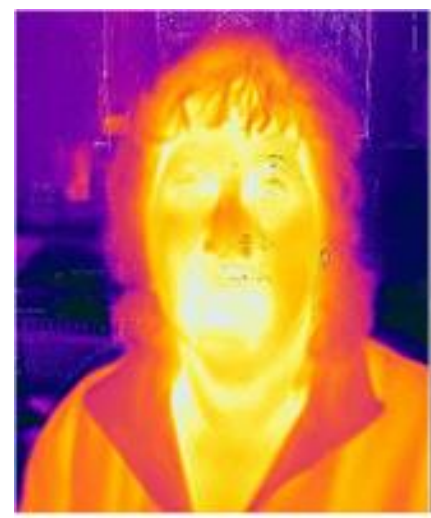

(a)

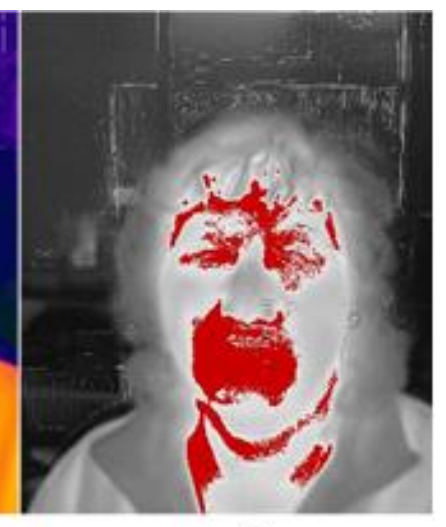

(b)
Fig. 14. a) Thermal image of the individual. b) Image of temperature greater than $38^{\circ} \mathrm{C}$ 


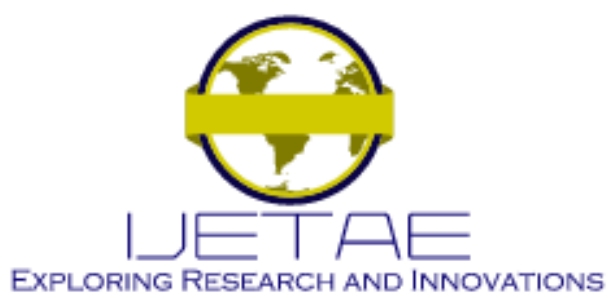

International Journal of Emerging Technology and Advanced Engineering

Website: www.ijetae.com (E-ISSN 2250-2459, Scopus Indexed, ISO 9001:2008 Certified Journal, Volume 11, Issue 11, November 2021)

We also have another photo that was taken of a person who had lenses, as can be seen in figure 15 (a), the image collected by the thermal camera, while in figure 15 (b), it is the image analyzed through thermal image processing. In this case, we observe that the lenses are an obstacle to be able to see the temperature in the sight, but that is not a problem for the system since the part of interest is the forehead.

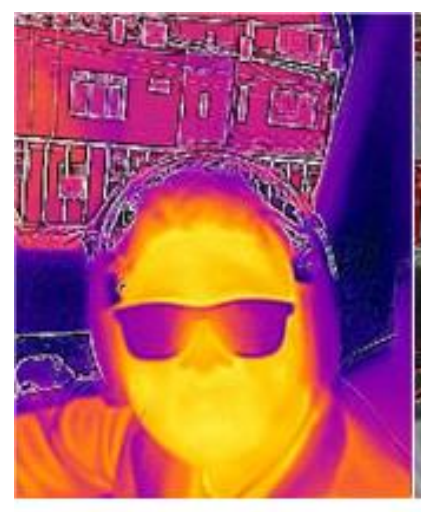

(a)

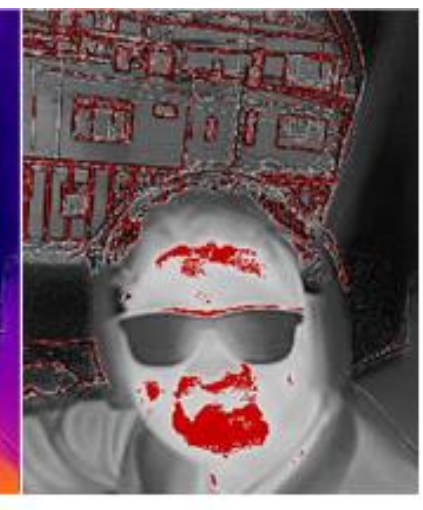

(b)
Fig. 15. a) Thermal image of the individual. b) Image of temperature greater than $34^{\circ} \mathrm{C}$

In addition, its implementation can take place in any place where such measurement is intended to be carried out, so it would be of great help to be able to combat the spread of the virus that continues to affect many people. Table I shows the characteristics obtained from the system for its correct operation.

TABLE I.

System Characteristics

\begin{tabular}{|c|c|}
\hline \multicolumn{2}{|c|}{ Thermal imaging } \\
\hline Distance & $50 \mathrm{~cm}$ \\
\hline Temperature range & $\begin{array}{c}\text { Normal: } 36.1^{\circ} \mathrm{C}-39.1^{\circ} \mathrm{C} \\
\text { High: } 40^{\circ} \mathrm{C} \text { o more }\end{array}$ \\
\hline $\begin{array}{c}\text { Place where the } \\
\text { image was captured }\end{array}$ & Forehead \\
\hline Rest time & 0 minutes \\
\hline
\end{tabular}

With the results obtained, this system meets all the expectations to avoid contagion between people. In addition, it has unique results that differentiate it from other research works. The principal characteristic of the research work is that we complement the thermal camera with the DRONE, there are many DRONES with thermal camera but they are so expensive that's why this research work aims.

\section{DISCUSSION}

The research articles about COVID-19, aim to provide a solution against this virus that is currently present throughout the world.

Currently, the present research work is a new topic against the virus, therefore, it differs from many research works, for example, the work carried out by [13], where the authors propose to develop a web system to monitor body temperature with an automatic antibacterial gel dispenser to prevent COVID-19 infections in commercial premises in Guayaquil. Although it is true, they had a result of $98.1 \%$, but this system only works in a certain place so its use would be limited.

We also have the research work done by [14], where the authors propose to develop an automatic recording system for forehead temperature measurement. Although it is true, they had a result of $98.5 \%$, but this system only performs the measurement for those people who have an RFID card.

We also have a research work done by [15], where the authors propose to perform an automated assessment of COVID-19 risk factors along with indoor and real-time personal location data for potential disease identification, prevention and smart quarantine. While it is true, they had a result of $97.7 \%$, but this system performs a simple measurement of body temperature.

We also have a research work done by [9], who proposed a security monitoring and prevention measures of COVID19 contagion through detection in CCTV system for mining, this research work only monitors if they comply with safety measures. Although it is true, it had a result of $98 \%$, but this system cannot detect the variation of people's temperature.

We also have a research work done by [16], who propose a COVID-19 detection system with biosensors based on graphene transistors, this research work only detects if a person is with COVID-19. While it is true, they had a result of $96 \%$, but this system cannot detect if a person has a temperature variation so it would have a limited performance. 


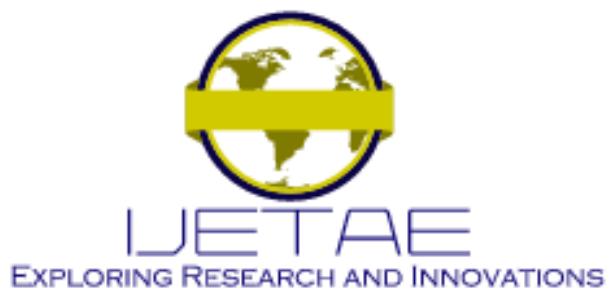

International Journal of Emerging Technology and Advanced Engineering Website: www.ijetae.com (E-ISSN 2250-2459, Scopus Indexed, ISO 9001:2008 Certified Journal, Volume 11, Issue 11, November 2021)

We also have a research work done by [17], who propose a system for detecting the fever of employees with the thermal camera, this research work only measures the body temperature of workers before entering their workplace. Although it is true, they had a result of $99.78 \%$, but this system cannot interact with people outside of their workplace so it would have limited operation.

\section{CONCLUSION AND RECOMMENDATION}

It is concluded that the system works in the best way, making the most accurate measurement of body temperature, therefore, its use will help reduce the number of infections. In addition, indicate that only the image of the individual is required without physical contact, thus helping to avoid contagion.

It is concluded that the system can be used in any place where a more precise measurement of the body temperature of people is required. This being very important since it has no limitations in its use, in addition to being a friendly system for the personnel in charge.

It is concluded that the system is completely safe, since, when manipulating it, the personnel in charge do not run the risk of catching the virus, since it complies with social distancing and there is no contact with any person. In addition, you have the measurement of body temperature instantly.

As work in the future, the implementation of the system will be carried out and the drone will be used with different people, so this system will serve to help prevent infections that are currently growing. This would prevent the spread of the virus. In addition, it will be tested at the Universidad de Ciencias y Humanidades to students and workers.

It is recommended to consider the distance between the drone and the person, it cannot be too far since it will take low-quality photos, nor too close since it could cause physical damage to the person with the propellers of the drone.

\section{REFERENCES}

[1] M. Palacios Cruz, E. Santos, M. Velázquez Cervantes, and M. León Juárez, "COVID-19, a worldwide public health emergency," Rev. Clínica Española (English Ed., vol. 221, no. 1, pp. 55-61, Jan. 2021, doi: 10.1016/j.rceng.2020.03.001.

[2] M. Adnan Shereen, S. Khan, A. Kazmi, N. Bashir, and R. Siddique, "COVID-19 infection: Emergence, transmission, and characteristics of human coronaviruses," J. Adv. Res., vol. 24, pp. 91-98, Jul. 2020, doi: 10.1016/j.jare.2020.03.005.

[3] F. Jirjees, Y. Dallal Bashi, and H. Al-Obaidi, "COVID-19 Death and BCG Vaccination Programs Worldwide," Tuberc. Respir. Dis. (Seoul)., vol. 84, no. 1, pp. 13-21, Jan. 2021, doi: 10.4046/TRD.2020.0063.
[4] D. Amsalem, L. Dixon, and Y. Neria, "The Coronavirus Disease 2019 (COVID-19) Outbreak and Mental Health: Current Risks and Recommended Actions," JAMA Psychiatry, vol. 78, no. 1, pp. 9-10, Jan. 2021, doi: 10.1001/jamapsychiatry.2020.1730.

[5] C. Apaza, R. Seminario Sanz, and J. Santa-Cruz Avéralo, "Factores psicosociales durante el confinamiento por el Covid-19 - Perú," Rev. Venez. Gerenc., vol. 25, 2020.

[6] U. Cáceres Bernaola, C. Becerra Núñez, S. Mendívil Tuchía de Tai, and J. Ravelo Hernández, "Primer fallecido por COVID-19 en el Perú," An. la Fac. Med., vol. 81, no. 2, pp. 201-205, Jul. 2020, doi: 10.15381/anales.v81i2.17858.

[7] C. Maguiña Vargas, "Reflexiones sobre el COVID-19, el Colegio Médico del Perú y la Salud Pública," Acta Médica Peru., vol. 37, no. 1, pp. 8-10, Mar. 2020, doi: 10.35663/amp.2020.371.929.

[8] C. Niño Rondón, S. Castro Casadiego, B. Medina Delgado, D. Guevara Ibarra, and J. Gómez Rojas, "Procesamiento de imágenes de video para verificar el distanciamiento social durante la pandemia de COVID-19," Rev. Logos, Cienc. Tecnol., vol. 13, no. 1, pp. 116127, Dec. 2020, doi: 10.22335/rlct.v13i1.1305.

[9] J. Musso Zapico, "Monitoreo de seguridad y medidas de prevención de contagio de Covid-19 mediante detección en sistema CCTV para la minería," Universidad de Chile, Santiago de Chile - Chile, 2021.

[10] E. Villanueva, Fernámdez. M., E. Viano, and M. Amorín, "Fiabilidad en la medición de la temperatura corporal con un termómetro timpánico en pacientes geriátricos," SCIELO, vol. 28, no. 2, pp. 68-72, Jun. 2020.

[11] W. S. Córdova Eras, "Implementación de un sistema de reconocimiento de distanciamiento social como medida preventiva para covid 19 usando deep learning," Machala: Universidad Tëcnica de Machala, Machala - Ecuador, 2020.

[12] R. Hilario Quispe, "Efectividad del uso del termómetro digital versus el térmometro infrarrojo en el paciente pediátrico," Universidad privada Norbert Wiener, Lima - Perú, 2020.

[13] K. Chicaiza Moncayo and G. Cordero Cerezo, "Desarrollo sistema web para monitoreo de temperatura corporal con dispensador automático gel antibacterial para prevenir contagios COVID-19 locales comerciales en Guayaquil mediante el uso de Arduino," Universidad de Guayaquil, Guayaquil - Ecuador, 2020.

[14] L. Sheng Hsiung and L. Ching Chun, "Automatic login system for forehead temperature measurement," Proc. - 2020 Int. Symp. Comput. Consum. Control. IS3C 2020, pp. 154-157, Nov. 2020, doi: 10.1109/IS3C50286.2020.00047.

[15] J. Barabas, R. Zalman, and M. Kochlan, "Automated evaluation of COVID-19 risk factors coupled with real-time, indoor, personal localization data for potential disease identification, prevention and smart quarantining," 2020 43rd Int. Conf. Telecommun. Signal Process. TSP 2020, pp. 645-648, Jul. 2020, doi: 10.1109/TSP49548.2020.9163461.

[16] F. Gámiz et al., "Detección de la COVID-19 con biosensores basados en transistores de grafeno," Granada - España, 57, Sep. 2020.

[17] A. Gupta, S. Maurya, N. Mehra, and D. Kapil, "COVID-19: Employee Fever detection with Thermal Camera Integrated with Attendance Management System," Proc. Conflu. 2021 11th Int. Conf. Cloud Comput. Data Sci. Eng., pp. 355-361, Jan. 2021, doi: 10.1109/Confluence51648.2021.9377079. 


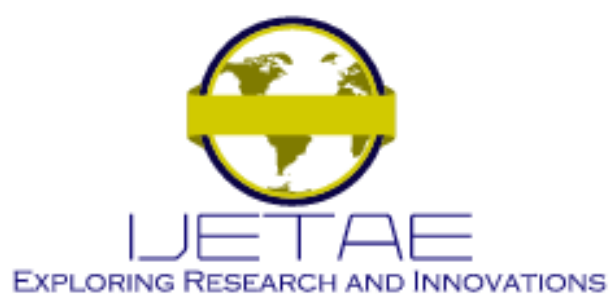

International Journal of Emerging Technology and Advanced Engineering

Website: www.ijetae.com (E-ISSN 2250-2459, Scopus Indexed, ISO 9001:2008 Certified Journal, Volume 11, Issue 11, November 2021)

[18] S. Sudha and S. Nagarajan, "Solar Charged Automated Drones Using Recognition Of The Institution In Zambia," J. Intell. Syst. Robot. Insights Transform., vol. 3, no. 1, 2019.

[19] C. Escobar Galindo, "Perfil antropométrico de trabajadores del Perú utilizando el método de escala proporcional," Ergon. Investig. y Desarro., vol. 2, no. 2, pp. 96-111, 2020.

[20] B. Meneses Claudio, W. Alvarado Díaz, F. Flores Medina, N. Vargas Cuentas, and A. Roman Gonzalez, "Muscles Heating Analysis in Sportspeople to Prevent Muscle Injuries using Thermal Images," IJACSA) Int. J. Adv. Comput. Sci. Appl., vol. 10, no. 6, 2019.

[21] Y. Pallo Jiménez, "Desarrollo de aplicaciones prácticas en la adquisición y procesamiento de imágenes en MatLab y LabVIEW," Universidad Católica de Santiago de Guayaquil, Guayaquil Ecuador, 2021.
[22] R. De Armas Costa, S. Quintero Torres, C. Acosta Muñoz, and C. Rey Torres, "La transformada de Radon aplicada a la segmentación de imágenes digitales en escala de grises," Rev. Ing. Univ. Medellín, vol. 17, no. 32, pp. 213-227, 2018, doi: 10.22395/rium.v17n32a10.

[23] Y. De la Cruz and J. Tinoco, "Determinación de la Calidad de Granos de Arroz Pulido Utilizando Algoritmos de Procesamiento Digital de Imágenes," Universidad Nacional Pedro Ruiz Gallo, Lambayeque - Perú, 2019.

[24] E. Alves and J. Ramos, "Numerical analysis of collapse modes in optimized design of alveolar Steel-concrete composite beams via genetic algorithms," REM - Int. Eng. Journal., vol. 74, no. 2, pp. 173-181, Apr. 2021, doi: 10.1590/0370-44672020740060.

[25] D. Montiel, E. Torres, M. Jarolin, V. Taboada, C. Alderete, and L. Negri, "Thrombotic thrombocytopenic purpura associated with COVID-19," Rev. salud publica del Paraguay, vol. 11, no. 1, pp. 117-120, Jun. 2021, doi: 10.18004/rspp.2021.junio.117. 